\title{
TEACHERS' PERCEPTIONS OF EDUCATION SUPPORT STRUCTURES IN THE IMPLEMENTATION OF INCLUSIVE EDUCATION IN SOUTH AFRICA
}

\author{
Author: \\ N. M. Nel ${ }^{1}$ \\ L. D. N. Tlale ${ }^{2}$ \\ P. Engelbrecht ${ }^{3}$ \\ M. Nel ${ }^{4}$
}

\section{Affiliation:}

${ }^{1}$ Department of Psychology

of Education, School of Educational Studies, College of Education, University of South Africa

${ }^{2} \mathrm{~S} c h o o l$ of education, Department of Psychology of Education, The University of South Africa

${ }^{3}$ Faculty of Education Sciences, North-West University Potchefstroom Campus

${ }^{4}$ FOptentia Research Focusarea North-West University, Vaal Triangle campus

Correspondence to:

Norma Nel

tnelnm@unisa.ac.za

\section{Correspondence to:}

Lloyd Tlale

tlaleldn@unisa.ac.za

\section{Correspondence to:}

Petra Engelbrecht petra.engelbrecht50@gmail. com

\section{Correspondence to:}

Mirna Nel

mirna.nel@nwu.ac.za

Dates:

15 Des 2016

\section{How to cite this article:} Nel, N.M., Tlale, L.D.N, Engelbrecht, P \& Nel, M, 2016. "Teachers' perceptions of education support structures in the implementation of inclusive education in South Africa". KOERS - Bulletin for Christian Scholarship, 81(3). Available at: https://doi.org/10.19108/ KOERS.81.3.2249

\section{Copyright:}

(c) 2016. The Author(s). Published under the Creative Commons Atribution License.
Inclusive education forms the ethos of the education system in South Africa and resonates with the Constitution of the country, which recognises diversity and resists exclusivity. Inclusive education is also reflected in education policies such as the Education White Paper 6: Special Education - Building an Inclusive Education and Training System and the Screening, Identification, Assessment and Support (SIAS) document. Pivotal to inclusive education is the provision of support for all learners and teachers. The focus of this paper is on the functionality of all the formal support structures that are in place for teachers and learners from the teachers' viewpoints. These support structures include District-Based Support Teams (DBSTs), Institutional-Level Support Teams (ILSTs), Full-Service Schools (FSS), Special Schools as Resource Centres (SSRC), Learning Support Educators (LSEs) and the community. An interpretive research paradigm was chosen, using convenience sampling and data was collected by means of focus group interviews. Constant comparative data analysis was employed. Peer review and member checks were used to ensure trustworthiness. The themes that emerged were support provided by teachers, the role of official support structures and special schools and community collaboration. It was evident, from the teachers' point of view, that the formal support structures are not as effective as proposed by policy and educational authorities and that the policy needs serious re-consideration.

KEYWORDS: District-Based Support Teams; Institutional-Level Support Teams; Full-Service Schools; Special Schools as Resource Centres; Learning Support Educators; Inclusive education

$$
\text { } \ldots \ldots \ldots \ldots \ldots \ldots \ldots \ldots \ldots \ldots \ldots \ldots \ldots \ldots \ldots \ldots \ldots \ldots
$$

Inklusiewe onderwys vorm die etos van die onderwysstelsel in Suid-Afrika en resoneer met die Grondwet van die land, wat diversiteit erken en eksklusiwiteit weerstaan. Inklusiewe onderwys word ook weerspieël in die onderwysbeleid soos uiteengesit in die Education White Paper 6: Special Education - Building an Inclusive Education and Training System and the Screening, Identification, Assessment and Support (SIAS) dokument. Deurslaggewend vir inklusiewe onderwys is die voorsiening van ondersteuning aan alle leerders en onderwysers. Die fokus van hierdie artikel is op die funksies van al die formele ondersteuningstrukture wat in plek is vir onderwysers en leerders en weerspieël die standpunte van onderwysers. Hierdie ondersteuningstrukture sluit in Distrikgebaseerde ondersteuningspanne; Institusionele ondersteuningspanne, Voldiensskole; Spesiale skole as hulpbronsentra; Leerondersteuningsopvoeders; inklusiewe onderwys en die gemeenskap. ' $\mathrm{n}$ Interpretatiewe navorsingsparadigma is gekies waarin gerieflikheidsteekproefneming gedoen is en data ingesamel is met gebruik van fokusgroeponderhoude. Eweknieen ledekontrole is gebruik om betroubaarheid te verseker. Die temas wat na vore gekom het was ondersteuning deur onderwysers, die rol van amptelike ondersteuningstrukture, spesiale skole en gemeenskapsamewerking. Dit was duidelik, vanuit die onderwysers se gesigspunt, dat die formele ondersteuningstrukture nie so effektief is as wat voorgehou word deur die beleid en die onderwysowerhede nie, end at die beleid ernstige herbesinning nodig het.

SLEUTELWOORDE: Distrik-gebaseerde ondersteuningspanne; Institusionele ondersteuningspanne, Voldiensskole; Spesiale skole as hulpbronsentra; Leerondersteuningsopvoeders; inklusiewe onderwys 


\section{INTRODUCTION}

In more and more countries, learners with disabilities and those experiencing diverse barriers to learning are gaining access to mainstream schools and curricula. It requires great effort over many years to prepare a school system as well as the schools to be inclusive contexts offering effective education. Seeing that children and communities differ greatly, there is need to find out what works for particular learners in particular schools and classroom situations. Inclusive education is thus an "evolutionary process". Instead of inclusion being a reform effort, schools are trying to integrate their human as well and their capital resources in order to offer integrated improvements to cater for all learners (Janney \& Snell, 2013:2-3, 9).

Research in South Africa has found that teachers report that they experience the implementation of inclusive practices in their classrooms as stressful and that contextual dilemmas such as the lack of formal support structures play an important role (Walton et al., 2014; Engelbrecht et al., 2003). This necessitates continuous teacher training, classroom support and teachers' necessary skills to know how to harness support within their own school community as well as at district levels (DoBE, 2011).

Policies, such as the Education White Paper 6: Special Education - Building an Inclusive Education and Training System (Department of Education, 2001) in South Africa require that inclusive practices be made available to everybody, everywhere and all the time (Ferguson, 2008:109-110). Donohue and Bornman (2014:1) regard current policy (White Paper 6) as being unclear and issues pertaining to poor implementation of the policy as the main factors hindering inclusive education implementation in South Africa. In addition, what remains troubling is that the rhetoric of inclusive education for learners with diverse educational needs is not adequately matched by reality. It has become increasingly clear that it is not enough to only offer these learners access to mainstream classrooms. What happens in the classrooms is also critical, specifically how all learners can participate meaningfully in the various learning activities and the levels of acceptance of learners with learning barriers by both teachers and their peers (Ferguson, 2008; Florian \& Black-Hawkins, 2010; Nel, Engelbrecht, Nel \& Tlale, 2013). Mittler (in Mariga, McConkey \& Myezwa, 2014: foreword) explains that inclusive education can succeed as long as there is "political will, good leadership, preparation of teachers and parental and community support" which is evidenced in countries such as Bangladesh, India, Kenya, Laos, Vietnam and South Africa.

Mariga et al. (2014:3) further report on success stories such as the situation in Lesotho. Since 1990 Lesotho has shown that the inclusive education programme has developed "without a wealth of resources". Its success resulted from the interaction between the government schools, NGOs and partnerships with the local communities. Nsamenang (2005:286) asserts that as long as Africa's development thinking and action are fixated on Eurocentrism, it will still elude Africa, and African development needs to be Afrocentric. However, a paucity of resources will result in this form of education being "unnoticed by national and international power blocks".
Given South Africa's unique history (apartheid), diversity (ethnic and language groups) and poverty, society has different ideas regarding the needs of learners with disabilities; their beliefs and what are best practices. These complexities compound the difficulties in implementing inclusive education (Donohue et al., 2014:3).

Inclusive education, as well as the search to find strategies to identify and remove barriers to learning in South Africa, is a never-ending process and it has, therefore, brought about huge challenges for education (Engelbrecht \& Green, 2007). Teachers continue to struggle with the implementation thereof, while they are also required to maintain high quality education practices (McLeskey, Waldron \& Reddy, 2014). As many as $65 \%$ of mainstream teachers do not have a formal initial teacher education qualification that included training in how to respond, within mainstream classrooms, to diverse learning needs (Dreyer, Engelbrecht \& Swart, 2012). They were either trained only for general mainstream education or so-called "specialised education" in separate educational settings. This model of initial teacher education and support for learners is based on a medical deficit approach, where specialised intervention is needed and support focuses on support by specialists in Education Support Services. The result has been that teachers believe that they are not able to provide the support needed in classrooms and that the needs of especially learners with disabilities are best met in separate classrooms (Armstrong \& Barton, 2008:6; Florian \& BlackHawkins, 2010; Florian \& Rouse, 2010:190; Devecchi, Dettori, Doveston, Sedgwick \& Jament, 2012:171; Donohue \& Bornman, 2014; Dreyer et al.., 2012:285-286; Geldenhuys \& Wevers, 2013; Hay, 2012; Nel et al., 2013), so subsequently, the majority of learners with disabilities still attend special schools (Donohue, 2014:2).

We thus concur with Ferguson (2008:113) who refers to the Systematic Change Framework (SCF) which emphasises that in an effort to make successful changes it should take place at all levels of the system such as the community, district, school, classroom and learners. One significant cause that could sustain the rhetoric of inclusion and hinder the successful practice of inclusive education is insufficient support to teachers and learners. It is thus necessary that a "multiagency, community-based partnership approach" is established to construct sustainable support systems (Armstrong \& Barton, 2008:6).

Donohue et al. $(2014: 4,6)$ allude to the contrast between the traditional and the biomedical views of disability by various authors as they commonly describe traditional views of disability as being handed down from generation to generation and the biochemical view as being "scientific, evidence-based practice of modern medicine". Donohue et al. explain that traditional teacher education either prepared teachers for general education or for special education (by-products of the medical model). However, currently, teacher education has moved towards the social model of disability which is rooted in the human rights paradigm whereby inclusion and participation for learners with disability are emphasised. 
As Hay (2012) points out, much has been written about the changes that the implementation of inclusive education in South Africa has engendered for education support services in schools and districts in an effort to move away from a traditional medical deficit approach to a more eco-systemic support approach. However, little has been documented about the reality and dilemmas teachers face in trying to provide educational support to learners with diverse educational needs in their classrooms and their perceptions of support structures within the South African education context. It is imperative that teachers make a mind shift in terms of their teaching practices and their attitudes (including cultural attitudes and values) towards learners with disabilities. However, support such as financial support and support for teachers and learners are pivotal for the successful implementation of inclusive education.

This study therefore focuses specifically on the perceptions of teachers about support structures and their own perceived needs in this regard. In the next section, the support structures which have been put in place in South Africa are discussed within an ecological systems approach.

\section{SUPPORT STRUCTURES WITHIN AN ECOLOGICAL SYSTEMS APPROACH IN SOUTH AFRICA}

The Education White Paper 6 (EWP6) (Department of Education, 2001), the policy on building an inclusive education and training system, provided key strategies with regard to the development of support structures. These strategies are clearly placed within Bronfenbrenner's ecological model. Bronfenbrenner (1979:3) describes the environment as a "set of nested structures" [micro, meso, exo, macro and chrono-structures] where each of these structures influences the development of the learner. Berns (2012:18) describes the microsystem as the innermost structure where the earliest effect on the learner is the interaction between the family, peers, childcare and school. Bronfenbrenner (1995:599-618) refers to these relationships as being bi-directional, meaning that adults influence the development of the learner and vice versa. Support for both learners and teachers should start in this innermost structure. If learners lack support by the adult (such as the teacher or other support personnel) at this early stage, they are already at a disadvantage. In addition, it also has an impact on the development of the learner when the adult - the caregiver and teacher - is not supported by other adults, such as colleagues and other professionals, in his or her endeavours to support learners with barriers to learning. The micro-system is contained in the second contextual structure, called the meso-system.

The interconnections of the components of the microsystem such as the home, siblings, family, school and development of the learner are the functions of the meso-system (Berns, 2012:20). Effective interaction between these micro-systems is essential, as it influences the ability of learners to achieve their optimal learning potential. It is, therefore, in the mesosystem where support is pivotal, as the reciprocal relationships between the above-mentioned role-players contribute to the optimal development of the child. All the support structures that will now be discussed fall under the meso-system.

The micro- and meso-systems are located in the exo-system. This structure contains role-players such as the extended family, the neighbourhood, the parents' work environments and the mass media (Berns, 2012:22). These factors can play an important role in the successful functioning of the support structures mentioned earlier; however, it does not affect the learner directly.

The macro-system is not context-based. It is the outer structure and it informs the micro-, meso- and exo structures. It consists of cultural values, customs, laws and national policies including, for example, the Education White Paper 6 (DoE, 2001). The larger principles affect the interactions of the other layers in a cascading manner (Paquette \& Ryan, 2001:2), and this directly affects the development of the learner. Public policy, for example, determines particular properties of the other three systems happening in everyday life which, in turn, has an influence on the behaviour and development of the learner (Bronfenbrenner, 1979:9). It is the policies that have been implemented to give effect to inclusive education, such as the EWP6 (DoE, 2001), the Screening, Identification, Assessment Strategy (SIAS) document (DoBE, 2014), Guidelines for Inclusive Learning Programmes (DoBE, 2010) and others that have an impact on teachers and learners in need of support.

The chronosystem involves temporal change in ecological systems or even in individuals, which produces new conditions affecting development (Berns, 2012:26). The dimension of time is encompassed in this system, because it is related to the environment of the child. Children react differently to environmental changes (Paquette \& Ryan, 2001) and it is therefore necessary that support structures take note of learners' and teachers' changing needs in order to successfully provide support.

Support structures for schools, teachers and learners in South Africa, as formulated by the various policy documents, are, as mentioned earlier, located in the meso-system. This includes the establishment of District-Based Support Teams (DBST), Institution-Level Based Support Teams (ILST) (also called school-based support teams), Full-Service Schools (FSS) as well as Special Schools as Resource Centres (SSRC). The responsibility of the DBST is "to provide a co-ordinated professional support service that draws on expertise in further and higher education and local communities, targeting special schools and specialised settings, designated full-service and other primary schools and educational institutions".

The EWP6 (DoE, 2001) refers to the first level of support for learners and teachers in a school as the Institution-Level Support Team (ILST). This team comprises teachers, volunteers, members of the school management team, members of the District-Based Support Team (DBST) and other stakeholders from the community (such as health professionals, other governmental departments and non-governmental organisations). Its key functions are to co-ordinate support services within the school by identifying and addressing 
learner, educator and institutional needs, the development of learner support programmes for learners, to provide training for teachers and to encourage collegial collaborative support and, ultimately, liaise with the DBST. Should the ILST not be in a position to support the learner/s and teachers, and then the DBST is the next level of support that should respond to the request from the school's ILST - for additional support for schools, teachers and learners and to monitor this support provision (Nel, Nel \& Lebeloane, 2013:56-57).

In his study, Makhalemele (2011) found that the DBST members indeed realise that their roles have changed and that they now include, inter alia, the provision of resources to schools; the evaluation programmes and suggestions for modifications; the provision of collaborative formal and informal support with communities, educational institutions and other sectors. It was also found in this study (Makhalemele, 2011) that the DBST members find it difficult to fulfil these changed roles. Currently, the DBST roles are not being executed successfully, which may be due to insufficient support received from the National Department of Education and because there is are gaps in the responsibilities of the national Department of Education, the provincial departments and the districts. In addition, there are other barriers that also hinder the DBST's service delivery. An example is the inadequate facilities and infrastructure that are available to DBST members to provide education support services at the district level, more specifically, the inadequate availability of transport for officials to visit schools and the limited human resources - which leads to overburdening of those district officials who are available.

The DBST needs to support, train and mentor those teachers who need it and they have to arrange specialised support from the SSRC (Johnson \& Green, 2007). These SSRCs should preferably be attached to schools in order for them to support the learners, teachers, parents and the community. By clustering mainstream schools that fall within the same jurisdiction of the SSRC, by conducting communal workshops for example, is one way of capacitating teachers in these schools (Makhalemele, 2011:201). The DBST must also ensure that the FSS has physical, material and human resources and provide the schools with support programmes which involve skilled or specialised personnel and the use of assistive devices (organised from a central point).

Where a learner needs an ISP and additional support/outplacement, the DBST needs to ratify this. In the case where learners have physical or sensory disabilities, they should be assessed by the DBST. Furthermore, the DBST must also assist teachers with the curriculum, to make it more flexible (in terms of their teaching methods and assessment); they must also provide illustrative learning programmes, learning support materials and assessment instruments; and on-going training and support to ensure that teachers make the curriculum accessible to all learners (Makhalemele, 2011:26-29).

In what is obviously a transdisciplinary approach, the SSRCs, DBSTs and hospital (therapists) services must be employed to assess what devices are needed and they should do the fitting thereof (Makhalemele, 2011:38), while the school must assist in giving learners free access to assistive devices through the Department of Health. Teachers should receive continuous support on how to use assistive technology and the DBST should also assist the subject advisors with the curriculum to make it more accessible for all learners (Makhalemele, 2011:45). Furthermore, full-service schools (FSS) should have the capability to deal with a diversity of learning needs, irrespective of the disability or differences in learning style or pace or social difficulties experienced. This should be done by establishing strategies to assist curriculum and institutional transformation as well as by providing additional support to teachers and learners from other mainstream schools (DoBE, 2010). Teachers at these schools also need to provide various levels of support to neighbouring schools, for example, they can share resources, skills and technology; ideas on how to prepare learning materials and good practice examples.

Special Schools as Resource Centres (SSRCs) should, in collaboration with the DBST and FSS, exchange knowledge with surrounding mainstream schools, provide professional development to teachers as well as sustainable support to learners and teachers (DoE, 2001; DoE, 2005). In recent years, Learning Support Educators (LSEs) have been appointed at District Offices as members of the DBST. These educators are assigned a number of schools where they provide assistance with regard to the identification and support of learners experiencing barriers to learning. At a national workshop entitled, "Learning for Democracy in an Inclusive Education System: Implications for Teacher Development", these LSEs were recognised as contributing immensely in building partnerships, providing teacher professional development, supporting the ILST and networking with community role players (DoE, 2005).

Research in South Africa has found that teachers experience the implementation of inclusive practices in their classrooms as stressful and they report that becoming effective in inclusive practices in a classroom can be demanding if there are limited and inefficient support structures available (Donohue \& Borman, 2014; Dreyer, 2011; Nel et al., 2013). Based on these results, the research question for the current study was formulated as follows:

What are teachers' perceptions of educational support structures within their schools and districts?

The following section gives an exposition of the research methodology that was employed during the second phase of the project.

\section{RESEARCH DESIGN AND METHODOLOGY}

The philosophical assumptions underlying this study were drawn from an interpretive research paradigm in which social phenomena are understood in the contexts in which they are constructed and reproduced through activities (Åkerlind, 2005). This decision was made in an attempt to obtain rich data about the meaning that a group of teachers assign to their perceptions of support structures within an 
inclusive education system (Merriam, 2009; Atkins \& Wallace, 2012; Nieuwenhuis, 2012). The data was collected during focus group interviews with teachers at selected schools in Gauteng.

The aim of the research was to develop an understanding of the support structures available to teachers and also to explore the different constructions and meanings that teachers place upon their experiences of available support structures in mainstream classrooms (Cohen, Manion \& Morrison, 2005).

\section{SELECTION OF PARTICIPANTS}

Convenience sampling was used, paying special attention to including schools from different socio-economic and cultural contexts and schools from various areas. With the assistance of a district official, participants were selected from three schools located in a low socio-economic area in Tshwane South, Gauteng. These schools were chosen because, according to the Tshwane South District Office, they had functional institutional level support teams (ILSTs), as defined in the Education White Paper 6 (DBE, 2001). It was believed that the research participants would be able to offer rich perspectives, based on their experiences as teachers. Of the three focus group interviews conducted at these schools, the first (one male and six females) and the third (two males and five females) focus groups comprised seven teachers, respectively, and the second group had six educators (all females). The total number of teachers involved in the focus group interviews was seventeen females and three males. All the educators are involved in the implementation of inclusive education and the majority have or are studying towards a qualification in inclusive education at an Open Distance Education university. The populations of the schools include South African learners as well as children from immigrant families, like Zimbabweans, Somalis and Kenyans.

We made it clear to the participants that we wanted to create a forum where we could all re-search (re-look at) issues connected with the implementation of inclusive education. The questions posed to the participants during the focus group interviews were as follows:

If you talk of support for learners in your classroom, what do you mean?

(The following probes were used where necessary: Describe specific support strategies - adaptations, accommodations and modifications. Did they help to assist you to implement inclusive education?)

How would you describe the social as well as the learning interaction of the learners in your classroom?

Ethical clearance for this research was obtained from the specific provincial education department and the participating universities. Permission from the relevant district offices, schools and selected teachers was obtained and we abided by all ethical issues.

\section{METHOD OF DATA COLLECTION}

Since the researchers employed qualitative methods, the data captured from the participants was obtained by way of focus group interviews and individual semi-structured interviews accompanied by a semi-structured interview schedule. The individual interviews served to enable the participants to reflect on the focus group interview process as a way to verify that the data captured by the researchers was true. This is a necessary part of the interview, as the participants do not only describe the experience, but they are also reflect on the description at the same time (De Vos et al., 2011:342).

\section{DATA ANALYSIS}

Qualitative data analysis as "a process of inductive reasoning, thinking and theorising" was used. The focus group interviews for this research were recorded and verbatim transcriptions were done manually.

Data was analysed using a constant comparative data analysis method. Basically, a constant comparative data analysis involves comparing the latest collected data with earlier collected data to determine differences and similarities and to identify common themes (Merriam, 2009; Glaser \& Strauss, 1967). As a result, a comprehensive coding scheme was developed. This means as categories were continually identified, new data was compared with existing categories. Different themes emerged and similarities were recognised (De Vos et al., 2011:402). To generate the categories we needed to note consistencies and as the categories emerged we looked for internal consistency, yet they needed to be distinct from one another (De Vos et al., 2011:410). We identified meaning units; we fixed them into categories and then assigned codes to them. This was the first level of coding.

The second level of coding involved interpreting the meaning of the first level categories, thereby reducing the data into smaller manageable themes. By means of selective coding, the core category was systematically related to other categories and then these categories were populated, refined and interrelationships were identified (De Vos, 2011:410-413; Merriam, 2009:21-22). Categories on the periphery were discarded when we arrived at saturation point.

In order to ensure trustworthiness of this study (plausible and credible data), member checking and peer review were employed (Creswell, 2007). With member checking we sorted the data and took our tentative interpretations back to the participants and asked them whether it was correct (Chilisa, 2007; Lincoln, 2009; Merriam, 2009). By using multiple researchers, as well as sources of data, emerging findings were confirmed. We also used peer review as a strategy to ensure validity and reliability and discussed with colleagues the research process as well as the congruency of emerging findings with the raw data and our first tentative interpretations (Merriam, 2009:9). 


\section{FINDINGS}

By grouping categories, the following themes were identified, namely,

\section{Support provided by teachers;}

Role of official/formal support structures;

Special schools; and

Community collaboration,

and these will be discussed below together with their subthemes.

\section{SUPPORT PROVIDED BY TEACHERS}

The support that teachers are able to offer learners falls within the confines of their own knowledge, skills and the resources available to them. As Loreman, Deppeler and Harvey $(2010: 3,7)$ rightfully profess, "teachers need to be highly skilled and motivated to be successful" as inclusion "demands such high levels of teaching competence and organisational changes" in order to promote effective learning. Although many teachers are positive about inclusion, the main areas of concern are training for inclusion; appropriate curricula for all learners; available resources and school and classroom structures that impede inclusion. The context and conditions in which the participating teachers in this study teach also make it difficult to support learners in their classrooms.

Participants ${ }^{1}$ in FG 1 responded as follows: I've got five children from Mozambique, I've got six children from Zambia, uh, I've got this child, he can't hear properly. I've got that child, he can't read. I've got this child, he's got behaviour problems. It's not happening. Another teacher in the focus group added. Now we've got, we've got 70 in a class. First of all, uh, it's a challenging situation because I can't reach them all. So even if I try to, to reach them there are so many obstacles that are preventing me to reach them....townships, they are staying in the informal settlements, they've got problems in their community that they are, their environment and their home and background. So there are so many challenges concerning the learner. Some come to school without food, although the government is trying to give them food here at school. Some have their, this, uh, problems with abuse which they don't, uh, cough it out to us. So it's, it's very much challenging, concerning, the, uh, reaching each and every learner. Uh, like, uh, for instance, those who cannot do their work, complete their work in class may think to remain after school so that I must reach them individually. Although, it's like I've already said, that some are not staying here, they're staying far from school and, it-it becomes a problem because they are no longer going-going to concentrate because they are thinking of going home - Especially those who have a severe food loss. Because I'm in a Grade 1 class

$1 \quad$ The responses of the participants are presented verbatim to do justice to the exact experiences expressed by the participants, especially in terms of frustrations and sometimes a downright sense of helplessness that are experienced. The responses are sometimes quite lengthy but serve to do justice to the feelings of the participants. and if there are, some it's their first year, especially for my school. So I, those who are having, uh, difficulties like, for example, maybe writing. I can, I just have to see to it that I put them in a position to reach them.

Teachers in this study indicated that they were able to give support on a one-to-one basis; however, the Curriculum Assessment Policy Statement (CAPS) (DoE 2011) limits them in terms of time, as it prescribes the time that the educator should spend on the different activities. A teacher in FG 1 explains that, for an example, there is a, I put them in one place. I-I can take one at a time and try to give him or her that extra lesson so that at least I can try and find him or her, to hold her, to try and write her name. Those are some challenges in Grade 1. If I can go to reading, I, or to write the name...

In addition the race against time is illustrated by a participant who says that this class is having a child with a wheelchair. What do they call that when he can't walk properly? But then, remember, ma'am having 46 learners in their class, Ma'am must look after that child, see to it that she goes to toilet, she helps her, leave the 46 - 45 - ja, and attend to that child. She does, she does go for therapy and all that, she does take medication. Uh, I don't think concerning medication I-I was, she's, I-I think she's on the right track with the medication and what. The only thing is that I-I-my worry is, X must leave those learners, attend to that one learner and it takes time and time, uh consuming because those other learners are, are going to be left behind. Uh-uh, ah. But the problems are, for her, you're supposed to, so slow ne, the progress is so slow, ne? - Because she's developing so slowly. Because the other learners, she's not at the level with them.

Other barriers that learners experience and that teachers try to support within the classroom situation are, inter alia:

FG1: They can't read. It's a serious problem. But we don't just sit and tell ourselves that, there are problems, we are just going to leave them. Ja, We have, I have developed some, a-a programme that the media programme, that I'm using for the, for those Grade 4s, I'm teaching, teaching Grade 4s. And the standard is for the Grade $1 s$. So - ja. At least at the moment they are trying to ja, coping. A little bit. And then we'll see when the, during December whether it helps. Another teacher adds that Uh, I'm in Grade 1. Uh, our problems are similar because you always share; um... we are three classes, $\mathrm{mm}$, three educators in the classes. Uh, what I saw in that class, learners are not, are not good in reading, some of them. And I try. I try to help them individually.

As one teacher informed the group that she supports learners: Right now the grade 7's through the remedial classes which many did agree uh-uh-uh for. This year most of our learners are much better. That's much better, they are okay, they are all, and they are able to read with the help of the remedial classes yes. The teacher continues... Like, for instance, let's say the child cannot, uh-uh-uh, write properly. Support him. Or train, give him activities where he can be praised and do something activities.

You put them together to help the other ones to count as well. And in the group work are you also doing that, uh, to take some people who are so-called a bit faster and some a little bit slower, and then they work together? 
The responses in FG 2 follow - Ja and giving him as much work as he can do. For example, this week I gave him a class work on Monday. He has not been able to finish it, it's Friday today. And I have been sitting with him here; I have to give the other class attention too.

Another participant explained that they are also traumatised by abuse. Learners sometimes have been abused. We are not experts in how to handle. We do refer to the-the-the authorities, maybe police, to come and see, uh, social workers. Last week was Child Protection Week so we had social workers coming, a different group of people coming. We do tell them and ask for advice from them but we are not specialists ourselves so we can do so much.

Another response from a participant was that there is a part that we are able to-to implement. For example, in remedial education we have been given a sort of a book where we photocopy activities and the learner does the activities but at the end of the day I don't know what to do if he is still not coping with those lessons.... it was, a-a workshop for one of the educators. And we were advised to go and use it if we, we have children who have those challenges. It does because it-it will give you maybe activities on-on background and foreground so that the child can...

But in terms of group work, uh, making sure that the other one helps the other one, because that is, uh, the other important issue. If you group them you also look, each one is stronger here, each one, so that you, the other one helps the-the-the-the others so that, you know, the influence this one.

They see us sharing. Even if you say, go and collect pictures, you say, if you have more, share with, uh, with other, other kids. Don't have three cows in your book. You must have different pictures and share. Give the friend.

FG3 participants responded as follows: $\mathrm{P} 1$ : So the very method that we are using is discussing in groups and so it's difficult for them if you go there, even if you give them different tasks, it's difficult to manage them because they are so many.

P2: Okay. I-I-I'm ... (inaudible). Um, what I try to do is, uh, I group learners according to their, to their abilities. Those learners who have, uh, maybe learning difficulties, I'm trying to put them with the learners who, who can be a little bit, those who abilities to-to do reading, for example. To be a major help, those who can't read.

P3: Like, we don't have enough, uh, teaching materials ..., what do you call that? Teaching...

P4: Because we don't have the resources, firstly, our classes are way too big. If you have 50, even in the intermediate phase, in a Grade 6 class, how many groups can I have? You think a Grade 6 child is going to really sit very quietly, even if it's a-a child that's achieving, he's not going to sit quietly while I'm working with a leaner who needs additional support.

P5: So I don't understand how are we supposed to do, um, remedial and supposed to do inclusivity with the kids in the class when we, physically there's no space in the class. You just can't have six groups in the class, work with one group and expect the other five groups to keep quiet in such a small class because there's 50-odd in the class.

But in six different groups, in one class, and it's difficult to control the noise level. So you're either very strict in the class and have a no, no talking policy because it, you can't ask them to whisper. It doesn't work. And then you have peer teaching but how do you know as a teacher that, what you're asking is being taught?

P6: No. With us we have three levels. We have level 1 whereby we will teach them all and then those who are better in level 1 can lloss of data due to overlapping conversations). Then meanwhile, those who are better in level 2, they go through to level three. There are those in level one they need your...

P1: I think because what I do often is, if I say something or explain something and I can see there's no reaction from them, I get one of the learners who is competent in-in-in the class and I ask him to say it back to me in English so that I know what she's telling me is the correct thing. And then I tell her to re-to-to say it to them again in Sepedi. So she's going to stand there and she's going to teach them in Sepedi. After I know what she said is correct in English.

P2: Another way is to do a lot of, uh, group - not group but, uh, pair work where they have to work with the person sitting next to them. Because between the two of them, one of them would have caught half of what I'm saying, the other would have caught some other half of what I'm saying. Between the two of them in their own language they can decide, you know, and work together. So I do a lot of, uh, group work like that. I don't do big group works because that doesn't work in my class.

The most significant access to an inclusive environment where learning needs to take place is physical access, as without it curricular and social access, for example, cannot happen (not only in the classroom but also all areas of the school). It should be done without being considered a luxury, but as the bare minimum required of the school to meet the needs of all the learners (Loreman et al., 2010:187, 189). “... For some students, assistive technology (AT) is a requirement for instruction because without it they cannot function academically... The same AT device that is used for one student to function may just be a useful support for another" (Ruedel, Fulcher, Diamond, O'Cummings, Jackson \& McInerney, 2005:42). Where the general curricula lack research-based alternative methods and materials which are needed to teach and assess learners, barriers can be created to the learning process. Supports such as digital media and technologies (computers, mobile devices, etc.) can expand instruction and provide "alternative paths of learning" (Ayala, Bracce \& Stahl, 2012:135).

\section{Teacher collaboration}

FG3: P1: I personally, uh, believe that, uh, information sharing it'sit's very good because there you will get the chance to listen to one another and, uh, hopefully learn from one another. It's good to hear other people's experiences. I mean, I've never been to Grade 1 class. I didn't know that X has got this difficult learner who she is, she needs to deal with and she can't because of these problems. It's very, very informative and very fruitful. 
Special educators and general educators need to engage in cooperative practices. Special educators need to learn or relearn the responsibilities and roles as well as the content of the general education. The general educators on the other hand, need to learn the "specialist jargon" and their expertise and find common ground in a working relationship. Teachers working cooperatively results in improved learning outcomes for learners as their expertise is shared and this leads to effective and continuous professional development (Ferguson, 2008:116).

Grenot-Scheyer, Fisher and Staub $(2001: 173,181)$ say that the cornerstones on which inclusive practices are constructed are collaboration, where families, learners, administrators and general and special educators are involved. Educators must thus set the stage for critical reflection "by those in and intersecting with our learning communities".

\section{Professional knowledge of teachers}

It was clear that teacher training with regard to inclusive education takes place at different levels including continuing professional development opportunities and initial teacher education. With reference to initial teacher education programmes, it seems to be mainly based on a medical deficit model approach. One teacher expressed her concern in this regard in the following way:

Ja that was going to be my first point, that mostly we are not trained for that disabled. We are training as mainstream educators so when you find a learner with any disability you can do the best that you can. But you reach a barrier also where you can't go over that barrier.

Another teacher, on the other hand, explained that she had done an additional Advanced Certificate in Education in Learner Support, which now enabled her to identify learners who are hyperactive; however, she was still not confident about her own level of professional knowledge and was not sure how she should support learners with disabilities effectively.

FG 1: P2: But sorry, X, my argument is that the system is failing us. The system is failing us. Why do I say that? Uh, after every four years you find that things are changing, education is changing. Education is changing. Education, how are we as teachers going to-to-to-to be developed? You-they are developing caps, next year it's something else, they say they are removing this then ...

FG2: P3: Even I, as a teacher, I didn't do remedial at school. So sometimes it's difficult to teach with those kids. It's very difficult.

P1: Ja that was going to be my first point, that mostly we are not trained for that disabled. We are training as mainstream educators so when you find a learner with any disability you can do the best that you can. But you reach a barrier also where you can't go over that barrier. For example, in my class I have just little boys who, uh, did Grade 1, completed Grade 1 and had to be moved to Grade 2 because the policy says.

FG3:P5: Yes. And I think also another major factor is that we haven't been developed in, in terms of inclusivity as such. In my mind inclusivity is having children with severe barriers, like ADHD and, um, autism and-and-and we will take - but it, it also includes the learner who can't read.

P4: And that for me is not inclusivity. That's a mainstream school with a problem, a child that's got a- a barrier. But you see now, we-we're not trained in terms of how do we deal with that specific child in that class. We were always told about ADHD and the huge problems that, you know the bigger problems. But the little ones we weren't told about. We weren't explained, we weren't taught, and we weren't given tactics as to how to deal with those specific learners in a big classroom. Because it's very nice to have group work but if you have 20 children you can easily do group work with the children. But if you have 50 children it becomes a major challenge.

P5: The Department, this issue of inclusive, it is, it's, it's good to a certain point. Because as these, uh, teachers who are coming to help us from the district, they look at these other kids that we refer them to and they look at what they're doing and they end up saying, this is in itself a-a-a-a disability. They come, these kids cannot go beyond, they are disabled in terms of going beyond whatever you are given, they cannot do anything. You give them this job, they can't, they can't write, they can't do anything - so inclusivity, yes, to a certain extent. But in-in-in-when I, if I were to support inclusivity I would say yes for the sake of kids, those, because some kids, you know, they want to feel included - so for that reason yes. But in terms of academic, uh, progress, uh, it's-it's-it's a serious challenge, because we are teachers and not really trained in remedial stuff like that. But for the sake of including other kids, I think basically the-then to include those kids, other kids to say, they must feel part of-ofother learners. They should not be excluded, stuff like that. That-that's a noble you know... Uh, in terms of academic, when you take these kids who are, who are very, very, very, very, very disabled academically and put them in the class, it's very-very difficult for teachers to budge because in most cases they are very destructive. Because they don't benefit, they can see, uh, what do I do? They start to engage in and disturb the other classes. So you, you have to put this kid here, give whatever the-thethe-the teachers are saying, they are giving them that for remedial. But after that you don't even know what this, is doing for this kid. Is it going to do this for the rest of his or her life? Is, is it really what this kid is, is there for? Or is it really another place where she or he can benefit? That is the question, for me that is the main question. Putting these kids here, is this kid just here to say, uh, I'm-I'm doing this remedial and there, thereafter what?

\section{PARENTAL INVOLVEMENT}

One of the challenges that teachers experience in their endeavours to provide support to learners who have barriers to learning is the non-involvement of parents and the fact that some parents are functionally illiterate. One participant expresses her frustration as follows:

Uh, the ones that I am dealing with, they have parents but their parents are not involved in the, in their education. You call them, you phone them, and they don't come. You find that the child cannot read and if the child cannot read, he cannot write a sentence. Yes. And they don't recall, uh, recognise that sounds, they 
need sounds so it's difficult to write, to formulate a simple sentence. Mm... So it's very difficult. Ja because they need support even at home, actual somebody to help them. So the parents, some of the parents are illiterate. Yes, Official support structures.

FG 1: P2: And what about, uh, parental involvement? Parents are no more interested in the education of their learners. We can't, you-you-you will be surprised if, if I tell you that, uh, we are issued reports in March but by now some parents have not yet come and collected them. How, as a parent, uh, don't you want to know about the progress of your child? Because somewhere along the line those who are parents, who are not coming here, are the same parents that, their children are having problems.

P3: It's going, it's go to write for that particular learner and even not explaining to the learner what it was all about, and what was all about. Coming to school the following day, when you check the homework, is the parent's handwriting. Not even the learner's handwriting. I usually then call the parents and then after you call the parents and they tell, or write in the, the book that, we don't write for children, we guide them. We-we-we show them what they must do and then they must. Since we have this ESSP, (Education Support System Programme) uh, this Education Support, uh, Support Programme which they come, these people come at 12 o'clock to assist the learners with homework.

P1: No. Sometimes-we issued letters to the parents to find out whether they are, they allow the children to remain in school forfor supervision of homework. Some parents and some parents are wanting. So there is, remember, those learners that are-are, the parents have disagreed to, you know.

Grades 6 and 7 is, um, is compulsory that they remain, uh, after school, even if they don't have homework. They must remain there and read. So they started, you know...

FG2:P4: It is very difficult, especially to deal with children, uh, from child headed, uh, households. Because you often give them homework, there's nobody to help. Even in the morning when you have given, given them reading activities, there's no one to help because he is looking after the siblings. Yes, so it's difficult for the child to cope in class. We do, I myself, I do let them stay during break, for ten minutes or 15 minutes but it's not enough. And then after school I cannot keep them because of the bus, because they stay farfar away from here. They-they can't walk.

P6: Now my problem is that parents are not involved in the teaching of their children. We call and we call and we write letters invite in that class, they don't respond. So it's very difficult to ... (inaudible) the child because you don't know the problem at home. Those parents, they don't avail themselves. You will write letters and you will phone. We use the school phone, they, we have records of their cell numbers. The p-parent will promise that I'll be coming on Wednesday. Ten Wednesdays later you-you're still waiting. Even if you call again, he won't, he or she won't say, I'm not coming. But you will see with their actions. You will even see, I phone them up when there-there is then the parents meeting, they will not attend. The parents that you really want, they will not attend.

\section{ROLE OF OFFICIAL AND FORMAL SUPPORT STRUCTURES}

\section{District-Based Support Teams (DBSTs)}

Teachers generally felt that referring learners to the DBST and requesting their assistance was a painstakingly difficult administrative exercise. A participant describes the process:

And you know, the processes to get support from District are such a mission that as a teacher, when do you get time to do it? It, you know what, it will take $\mathrm{X}$ longer to get the permission to get the support thanthan, what's the point? Because the processes that you must go through, the forms that you must fill out and the red tape that's involved, she's going to give up hope eventually.

The process that teachers need to follow, such as filling in forms on a daily basis and contacting the parents, is time-consuming. Despite their requests for assistance from the DBST, they get the following types of responses:

I am here to train you or to give you policy and material, go and read the policy. When I come to your class I am coming to see you practising it and then telling you if you are right or wrong. But the time that we need is to be helped practically on how to deal with that matter. And that's what is lacking.

However, responses also reflected that teachers do refer their challenges to the District and that the officials do come to school and help and advise them on how to help the learners. They explained that they do have a professional relationship with the DBST and that they have meetings with them, that they submit reports to them, that they monitor the effectiveness of the School-Based Support Team and that once the ILST (teachers refer to it as school-based support team, SBST) has referred the learners to the DBST, that learners are referred to. Further, the DBST has introduced different committees - such as HIV and AIDS, school health and safety and security committees - at schools, with guidelines about how these committees should operate, as an intervention measure; however, these committees demand a great deal of paperwork. The school governing bodies are not always available to assist in drawing up these policies and, because the syllabus changes regularly, teachers find it difficult to find the time to attend to this. Teachers requested that there should be an easier way of referring learners, without the tedious paperwork. To exacerbate the problem, there are fewer schools where learners with special needs (LSEN) can be referred to, as many of these specialised schools have been closed and those teachers absorbed in the districts. Where learners are referred to the DBST, there is no record to track their progress and often learners are seen "loitering outside, they are not returned to the mainstream if they have improved or they are not referred further to those relevant schools special or specialised schools so we lose track because there is no system in place that makes us to track them down and know what has happened to our learners". 
FG3: P2: Yes. She's bullying them. And, you know, I can't control her. So what I'm expecting is that, uh, because the-the-the people from the District keep on coming here and they see her, and they do nothing. And you know, the processes to get support from District are such a mission that as a teacher, when do you get time to do it? It, you know what, it will take $X$ longer to get the permission to get the support than-than, what's the point? Because the processes that you must go through, the forms that you must fill out and the red tape that's involved, she's going to give up hope eventually. After identifying the child you try to help her and then we have these forms that you must fill in every day. You see, it's a lot of work. You must sit down and fill the forms, you call the parent, explain to the parent that this child is, uh, not coping here and there, and try this, and then the parent must, it's either she or he agrees or she doesn't. He will say or she will say, at home she reads and Oh, they listen to you. They listen to you but they can't do anything. They tell you they are told to tell you what to do.

FG2:P3: When people come to help us who are supposed to be helping us, sometimes they, their personalities and ours clash. You find that the person wants to show you, I'm your senior. And then you don't need them, you need support, help, on how to deal with this and this and this and you find that the time that you have is not given the proper, you know, support. You are not given the proper support. But we live with it.

P1: That is so true. We have been requesting our coaches, our District, uh, help, uh, subjects for learning area facilitators to please come and tell us in the class, when I'm sitting with my boy in class who is giving me a problem, how do I help this child? But the answer we usually get is that, I am here to train you or to give you policy and material, go and read the policy. When I come to your class I am coming to see you practising it and then telling you if you are right or wrong. But the time that we need is to be helped practically on how to deal with that matter. And that's what is lacking. We are always having the same problem but we are not getting solutions because the training we're getting is not reaching that experienced level.

FG 1: P6: That is, mostly it because you find that the person who has been appointed in the higher position was never in class sometimes. And they do not understand what exactly is happening in class. Or, I was teaching an-a senior class and I'm now an HOD or a subject advisor for a junior class so I know the work for the higher class but I wanted this job at the District. So when I have to come to the class and actually do the work, there is a barrier or a...

\section{INSTITUTIONAL-LEVEL SUPPORT TEAM (ILST).}

It would appear that, to a certain degree, ILSTs function the way they are supposed to at selected schools. At ILST meetings, difficult cases are referred to the District and the officials provide advice to the teacher on how to help the learners. An ILST co-ordinator explained that she tries her best to see that learners are supported and that they complete the referral forms; however, it is a challenge as teachers are reluctant to complete the referral forms. It is encouraging to note that the particular school has a management plan in place.

FG2: It is functioning. We meet and we give, uh, one another activities, mainly. If we meet challenges that we cannot face we refer them to District. We have District educators coming to the school and they help us with advising us on how to help the learner.

Tebid (2010:61-67) reports that the FP teachers receive support from the learning support educator rather than the ILST (which is not coordinated properly), and it can therefore be concluded that should the ILST be properly organised, teachers will be better motivated as they will have knowledge, confidence and a change of attitude. Regarding parent support, parents are faced with many challenges inter alia, lack of transportation to attend school meetings. Despite these challenges, it is imperative that parents be made aware of the importance of their support and involvement in their children's learning. In addition, FP teachers recommend that more time is needed for regular meetings with the ILST; that more human resources are needed such as psychologists and social workers to support the learning support educator; that the DBST should not only train the ILST members but also organise in-service training for all teachers regarding inclusive education and addressing barriers to leaning and that more qualified and dedicated teachers be employed by the education department and reduction of paperwork which overburdens teachers. In addition, Dreyer et al. (2012:279) also found in their study that sport and cultural events took precedence over ILST meetings and that some mainstream teachers did not understand the purpose and function of the ILST as they regarded it as the responsibility of the learning support teacher. The learning support teachers on the other hand posed factors which impede the functioning of the ILST such as it being an advisory session and as an "automatic referral" system to withdraw learners from the mainstream classroom in order to provide support to learners elsewhere, instead of a collaborative, consultative team which aims to find best possible solutions.

\section{LEARNING SUPPORT EDUCATORS (LSE)}

Teachers explained that the District Office LSEs visit four to five schools in their jurisdiction and that they visit each school once a week and assist in identifying learners experiencing barriers to learning. Their main aim is to support educators and learners. They provide suggestions to address the identified challenges and then follow up on the implementation. Should the problems persist they offer support, provided that the teachers are specific in stating their needs for support and are able to identify the barrier.

\section{SPECIAL SCHOOLS}

The topic of special schools came up as teachers still need to place learners with barriers to learning in these schools and they also needed advice from these schools about how they can provide support to these learners. Teachers were of the opinion that the government was not putting in enough effort in assisting special schools and was underestimating the important role special schools play in providing support to mainstream schools. Loreman et al. (2010:11) recognise that extra funding is important; however, it is not necessarily crucial for the success of inclusion. 
FG 1: Yes. They even agreed it by giving an, an example of one, one white child who was in the mainstream, the parents had, I want my child to go .... X started then the parents, the-the teachers at the school are forced to go, uh, to get the training for, uh, Braille - So that they can accommodate that child.

\section{Community collaboration}

Teachers do refer learners to other community support structures such as the police, social workers, ministers of religion and nurses; however, they are not confident about whether the services they enlist are suitable for the problems they confront. A participant explained that:

We are not experts in how to handle. We do refer to the-the-the authorities, maybe police, to come and see, uh, social workers. Last week was Child Protection Week so we had social workers coming, a different group of people coming. We do tell them and ask for advice from them but we are not specialists ourselves so we can do so much.

The future role of the school-based occupational therapist, for example, in inclusive education is not only to work on a oneon-one basis with learners with disabilities but also to support teachers and empower them to participate in advocacy and the development of policies, to participate in multidisciplinary team collaboration and to support parents and community development (Sonday, 2012:5).

\section{DISCUSSION}

Inclusive education is an international practice that is accompanied by many tensions and dilemmas which can only be understood within the context in which it is taking place (Singal \& Rouse, 2003:85). Within the South African context, the Education White Paper 6 has mapped the way for the implementation of inclusive education and associated support structures feature as a pivotal aspect thereof. As discussed earlier, these support structures comprise District-Based Support Teams, Institutional Level Support Teams, Full-Service schools and Special Schools as Resource Centres and this paper reports on these as well as other forms of support that are available to teachers, from the participants' perspectives.

Since Bronfenbrenner's Ecological Systems Approach underpins this study, it is appropriate to situate the findings and their implications within this particular approach. It was in the micro-system, the meso-system and the macro-system where the support structures are mainly situated, such as the DBSTs, ILSTs, LSEs, as well as SSRCs and where most of the data was collected.

It was found that teachers felt that they were able, to some extent, to offer support to learners on a one-to-one basis; however, they were prevented from doing so by the demands of the Curriculum Assessment Policy Statement (CAPS), lack of transport, poor socio-economic environments that the learners come from and because of the lack of parental involvement. Another challenge was teachers' qualifications, which were on different levels and which leaned mostly towards the medical deficit model. It is challenges such as these and factors such as trust, resourcing, support and workload that cause teachers to leave the profession. With reference to lack of support, inadequate use of ICT resources, limited space and resources, inadequate teacher training, teachers' workload, parental support; collegial support for teachers starting their careers are contributing factors (MacBeath 2012:11). Du Toit and Forlin (2009:644), as well as Swart and Pettipher (2005) argue that for inclusion to work in South Africa and for schools to change, an enhanced education system is needed, which will provide the necessary infrastructure, resources and support.

Within the macro-system, the teachers reflect that the DBST, as a support system, does have its advantages, since they assist teachers by providing them with advice about how to identify learners with barriers to learning, they do organise meetings with teachers, monitor the ILSTs and assist with learner referrals to other institutions. Despite these efforts, teachers are in need of practical solutions/strategies to support learners who experience barriers to learning and they find the referral procedure tedious. The ILSTs are also functional to a degree. They conduct meetings to discuss learners who experience barriers to learning; however, teachers are reluctant to refer learners discussed in ILST meetings to the DBST for intervention. Other support structures, such as the LSEs, do assist on an itinerant basis. Learners are also placed in SSRCs however these schools lack in supporting mainstream schools. Teachers also feel that community collaboration is limited. Forlin and Chambers (2011:30) stress that for teachers to receive long-term, support, educational systems need to mentor new teachers and provide appropriate professional development on a continuous basis.

As Smit and Mpya (2011:33-34) advise, teachers "need to be equipped with knowledge, skills, strategies and a positive attitude" in order for inclusive classroom to be successfully managed by them. These authors argue that in order for teachers to do so, they need training which is adequate and they must receive support from specialists. To teach teachers is one of the most demanding professional preparations and, institutional support is of the essence, as it cannot be done in a context which is unsupportive or even conflicting (Darling-Hammond, Hammerness, Grossman, Rust \& Shulman, 2005:111). As teachers' classroom practices need to change, they need to support inclusive programmes and be well-prepared in how to do this and it is, therefore, critical for them to participate in high-quality professional development programmes. The programmes need to cater for the individual needs of the school and be part of the schools wider plan for improvement. These authors recommend a slow, school-byschool approach which is effective in order to change teacher classroom practices in an effort to improve learner outcomes (McLeskey \& Waldron, 2002:159, 170).

Jordan et al. (2009:541) are convinced that where teachers are given the opportunity within a supportive context to reflect and discuss the implications and the corollaries of their perspectives which may shed light for teachers on how change in beliefs and attitudes can lead to effective teaching practices for all learners. 
Furthermore, Florian (2008:205) questions how teachers can be supported to gain knowledge, beliefs and practices that will support inclusion and offers the following three concepts:

- difference must be pivotal right from the onset of teacher education and professional development;

- teachers need to rid themselves of the belief that they are not equipped to teach learners with disabilities or those who have additional needs; and

- teachers need to learn new strategies in order to work "with and through others."

It is also clear that the current South African socio-economic context may not allow inclusive education to be successfully implemented as there is a dire need for access to resources and facilities (Pillay \& Di Terlizzi, 2009:491, 505). Various researchers recommend that more funding is needed for technical and professional support, including adequate Learner Teacher Support Materials in order to provide teachers and learners with different ways to approach learning tasks at different levels (Swart \& Oswald, 2008; Donohue \& Bornman, 2014; Dreyer, Engelbrecht \& Swart, 2013; Pillay \& Di Terlizzi, 2009). In addition, the establishment of collaborative support teams, based on a trans-disciplinary approach within schools and districts, including groups of therapists, can be regarded as a strategy that will facilitate effective interventions and support learners and teachers in classrooms (Engelbrecht \& Green, 2007). Savolainen, Engelbrecht, Nel and Malinen (2012:17) advise that collaborative support networks need to be established; however, teachers lack confidence to do so, which needs to receive attention as well as the contexts in which these networks play in teacher education programmes.

\section{CONCLUSION}

As Johnson and Green (2007) point out, an inclusive approach to education both implies and is facilitated by a different understanding of education support. Formal support structures at district and school levels can facilitate collaboration and the sharing of expertise to provide adequate support within mainstream classrooms. Based on our research results, the question remains: to what extent does formal support focus on providing teachers with the necessary knowledge and skills to provide effective learning support to learners or to what extent is it still focused on identification and referral to other education contexts?

Ferguson (2008:113) refers to the Systematic Change Framework (SCF) which emphasises that in an effort to make successful changes it should take place on all levels of the system such as the community, district, school, classroom and learners. It is the responsibility of the District to make ensure the implementation of policies which support schools and to use the resources as flexibly as possible. On the school level teachers need to be granted space to plan, learn and work as a team and to be encouraged to use robust processes to assess and teach their learners.

It is widely recommended that initial teacher education programmes need to be restructured in an effort to prepare them for teaching in inclusive settings. It has been found that pre-service teachers benefit when they are instructed on specific collaboration behaviours especially when they have opportunities to collaborate with special and ordinary teachers during their training. Where their training program includes shared courses and field experiences (as early as possible in the course) it is more effective than teaching them, collaborative skills without practice in collaboration (Laarhoven, Munk, Lynch, Bosma \& Rouse, 2007: 440-441). Armstrong and Barton (2008:6) also stress the urgent attention to initial teacher education and professional development courses which needs to relate to inclusive thinking and practice.

Various researchers (e.g. Donohue \& Bornman, 2014:1; Du Toit \& Forlin, 2009:644) argue that for inclusion to work in South Africa and for schools to change, enhanced education which provides necessary infrastructure, resources and support and cultural transformation is needed. As Smit and Mpya (2011:3334) advise, teachers "need to be equipped with knowledge, skills, strategies and a positive attitude" in order for inclusive classroom to be managed by them. These authors argue that in order for teachers to do so, they need training which is adequate and receive support from specialists. To teach teachers is one of the most demanding professional preparations and most importantly institutional support is of the essence as it cannot be done in a context which is unsupportive or even conflicting (Darling-Hammond, Hammerness, Grossman, Rust \& Shulman, 2005:111). As teachers' classroom practices need to change they need to support inclusive programmes and be well prepared as it is critical for them to participate in high-quality professional development programmes. The programmes need to cater for the individual needs of the school and be part of the schools' wider plan for improvement. These authors recommend a slow, school-by-school approach as being effective in order to change teacher classroom practices in an effort to improve learner outcomes (McLeskey \& Waldron, 2002:159, 170).

Pillay and Di Terlizzi (2009: 491, 505) assert that the "current South African socio-economic environment does not necessarily allow for its [inclusive education] successful implementation, as further access to resources and facilities need to be made available". The authors recommend that more funding is needed for Learner Teacher Support Materials in order to provide teachers and learners different ways to approach learning tasks on different levels. In addition "multidisciplinary therapy teams" need to be operating regularly in schools or alternatively "mobile therapist clusters" that can assess and do intervention and support learners and teachers in classrooms.

\section{Declaration of conflicting interests}

The author(s) declared no potential conflicts of interest with respect to the research, authorship, and/or publication of this article.

\section{Funding}

The author(s) received no financial support for the research, authorship, and/or publication of this article. 


\section{REFERENCES}

Åkerlind, G. 2005. Variation and commonality in phenomenographic research methods. Higher Education Research \& Development, 24(4), 321-334.

Armstrong, F. \& Barton, L. 2008. Policy, experience and change and the challenge of inclusive education: the case of England. Policy, Experience and Change 5(18): 5-18.

Atkins, L. \& S. Wallace. 2012. Qualitative research in education. Los Angeles, CA: Sage.

Ayala, E., Brace, H.J. \& Stahl, S. 2012. Preparing teachers to implement universal design for learning. In: Eds.: T.E. Hall, A. Meyer and D.H. Rose. Universal design for learning in the classroom. New York: The Guilford Press.

Berns, R. 2012. Child, family, school community: Socialisation and support. Wadsworth Publishing: Belmont, CA.

Bronfenbrenner, U. 1979. The ecology of human development: Experiments by nature and design. Cambridge, MA: Harvard University Press.

Bronfenbrenner, U. 1995. The bioecological model from a life course perspective:

Reflections of a participant observer. In: Moen, P. Elder Jr., G.H. \& Luscher, K. (eds.). Examining lives in context. Washington, DC: American Psychological Association: pp. 599-618.

Chilisa, B. 2012. Indigenous research methodologies. Los Angeles, CA: Sage Publications, Inc.

Cohen, L.; Manion, L. \& Morrison, K. 2005. Research methods in education. 2nd Edition. London: Routledge-Falmer Publishers.

Creswell, J.W., 2007. Qualitative inquiry and research design: Choosing among five approaches, 2nd edition. Thousand Oaks: Sage

Darling-Hammond, L., Hammerness, K., Grossman, P., Rust, F. \& Shulman, L. 2005. The design of teacher education programs. (In L. Darling-Hammond, J. Bransford, P. LePage, K. Hammerness, \& H. Duffy (eds.). Preparing teachers for a changing world: What teachers should learn and be able to do. San Francisco: Jossey-Bass. pp. 390-441).

Department of Education, 2001. Education White Paper 6 (Special Needs Education) Building an Inclusive Education and Training System. Pretoria: Government Printers.

Department of Education. 2005. Conceptual and operational guidelines for the implementation of Inclusive Education: District Support Teams. Pretoria: Department of Education: Government Printers.

Department of Education, 2014. National Strategy on Screening, Identification, Assessment and Support (SIAS) - Operational Guidelines. Pretoria: Department of Education: Government Printers.

Department of Basic Education, 2010. Guidelines for Full-service/Inclusive Schools. Pretoria: Government Printers.

Department of Education, 2011. Curriculum and Assessment Policy Statement (CAPS) - Foundation Phase Home Language Grades R-3. Pretoria: Government Press.

Devecchi, C., Dettori, F., Doveston, M., Sedgwick, P. \& Jament, J. 2012. Inclusive classrooms in Italy and England: the role of support teachers and teaching assistants. European Journal of Special Needs Education, 27(2): 171-184.

De Vos, AS, Strydom, H, Fouche, CB \& Delport, CSL. 2011. Research at grass roots: For the social sciences and the human service professions. 4th edition, Pretoria: Van Schaik.

Donohue, D. \& Bornman, J. 2014. The challenges of realising inclusive education in South Africa. South African Journal of Education: 34(2), 1-14.
Dreyer, L.M Engelbrecht, P. \& Swart, E. 2012. Making learning support contextually responsive. Africa Education Review 9(2): 270-288.

Dreyer L.M. 2011. Hope anchored in practice. South African Journal of Higher Education, 25:56-69.

Du Toit, P. \& Forlin, C. 2009. Cultural Transformation for Inclusion, What is Needed? A South African Perspective. School Psychology International 30(6): 644-666.

Engelbrecht, P. \& Green, L. 2007. Responding to the challenges of inclusive education: an introduction. Pages 8-88. In P. Engelbrecht \& L. Green (Eds.). Responding to the challenges of inclusive education in Southern Africa. Pretoria; Van Schaik.

Ferguson, D.L. 2008. International trends in inclusive education: the continuing challenge to teach each one and everyone. European Journal of Special Needs Education. 23(2): 109-120.

Florian, L. \& Rouse, M. 2010. Teachers' professional learning and inclusive practice. Pages 185-199. In: Confronting obstacles to inclusion: international responses to developing inclusive education. Editor: R. Rose. London: Routledge.

Forlin, C. \& Chambers, D. 2011. Teacher preparation for inclusive education: increasing knowledge but raising concerns. Asia-Pacific Journal of Teacher Education 39(1): 17-39.

Geldenhuys, J.L. \& Wevers, N.E.J. 2013. Ecological aspects influencing the implementation of inclusive education in mainstream primary schools in the Eastern Cape, South Africa. South African Journal of Education, 2013; 33 (3), 1-13.

Glaser, B., \& Strauss, A. 1967. The discovery of grounded theory. Chicago: Aldine

Hay, J. 2012. The dilemma of a theoretical framework for the training of education support services staff within inclusive education. Journal for New Generation Sciences, 10 (2), 92-103.

Janney, R. \& Snell, M.E. 2013. Modifying schoolwork. $3^{\text {rd }}$ edition. Maryland: Brookes.

Johnson, B. \& Green, L. 2007. Thinking differently about education support. In P. Engelbrecht \& L. Green (eds.). Responding to the challenges of inclusive education in Southern Africa. Pretoria: Van Schaik. (pp. 159-174).

Lincoln, Y. S. 2010. What a long, strange trip it's been ... . Twenty-five years of qualitative and new paradigm research. Qualitative Inquiry, 16(1), 3-9.

Loreman, T., Deppeler, J. \& Harvey, D. 2010. Inclusive education: supporting diversity in the classroom. London: Routledge.

Makhalemele, T.J. 2011. The changing role of District-Based Education Support Services in establishing the inclusive school settings: an ecosystemic approach. PHD Thesis. North-West University.

Malinen, O., Savolainen, H., Engelbrecht, P., Xu, J., Nel, M., Nel, N. \& Tlale, D. 2013. Exploring teacher self-efficacy for inclusive practices in three continents. Teaching and Teacher Education, 33: 34-44.

MacBeath, J.2012. Future of teaching profession. Education International Research Institute. University of Cambridge, Faculty of Education. Leadership for Learning. The Cambridge Network. (pp. 1-112).

Mariga, L., McConkey, R. \& Myezwa, H. 2014. Inclusive education in low-income countries. Cape Town: Megdigital.

McLeskey, J. \& Waldron, N.L. 2002. Professional development and inclusive schools: Reflections on effective practice. The Teacher Educator, 37(3), 159172.

McLeskey J., Waldron N.L., \& Reddy L. 2014\. A case study of a highly effective, inclusive elementary school. The Journal of Special Education, 48(1) 59-70. 
Merriam, S. B. 2009. Qualitative research: A guide to design and implementation. San Francisco, CA: Jossey-Bass.

Nel, N.M., Nel, M. \& Lebeloane, L.D.M. 2013. Assessment and learner support. In: Learner Support in a Diverse Classroom. NM Nel, M Nel \& AJ Hugo (eds.). Pretoria: Van Schaik.

Nel, M., Engelbrecht, P., Nel, N.M. \& Tlale, L.D.N. 2013. South African teachers' views of collaboration within an inclusive education system. International Journal of Inclusive Education, 18 (9), 903-917.

Nsamenang, A.B. 2005. Educational development and knowledge flow: local and global forces in human development in Africa. Higher Education Policy, 18, 275-288.

Nieuwenhuis, J. 2012. "Analysing qualitative data." In First steps in research. K. Maree (ed.). Pretoria: Van Schaik. (pp. 99-117).

Paquette, D. \& Ryan, J. 2001. Bronfenbrenner's ecological systems theory. The Virtues Project: National Louis University.

Pillay, J. \& Di Terlizzi, M. 2009. A case study of a learner's transition from mainstream schooling to a school for learners with special educational needs (LSEN): lessons for mainstream education. South African Journal of Education, 29, 491-509.

Ruedel, k., Fulcher, A., Diamond, C., O'Cummings, M., Jackson, S. \& McInerney, M. 2005. Assistive technology and universal design for learning in content areas. In: Universal design for learning: A guide for teachers and education professionals. J. Castellani. (ed.). Council for Exceptional Children. United States of America: Pearson.

Savolainen, H., P. Engelbrecht, M. Nel, \& O. Malinen. 2012. “Understanding teachers' attitudes and self-efficacy in inclusive education: Implications for pre-service and in-service teacher education." European Journal of Special Needs Education, 27 (1), 51-68.

Singal, N. \& Rouse, M. 2003. "We do inclusion": Practitioner perspectives in some "inclusive schools" in India. Perspectives in Education 21(3), 85-97.

Smit, E. \& Mpya, G.N. 2011. How educator perception has shaped inclusive teaching in a rural village school in South Africa. Child Abuse Research: A South African Journal, 12(2), 25-35

Swart, E. \& Oswald, M. 2008. How teachers navigate their learning in developing inclusive school communities. Education as Change, 12 (2), 91-108.

Swart, E. \& Pettipher, R. 2005. A framework for understanding inclusion. In Landsberg E, Kruger, D. \& Nel, N.M. (eds). Addressing barriers to learning. A South African perspective. Pretoria: Van Schaik 